ISSN: 2548 - 1843

\title{
FAKTOR - FAKTOR YANG MEMPENGARUHI PELAKSANAAN KONSEP TERAPI BERMAIN TERHADAP PENERAPANNYA DI RUANG ANAK RS HUSADA JAKARTA
}

\author{
Dameria Saragih*)
}

*)Dosen Akademi Keperawatan RS Husada, Jakarta, 10730, Indonesia

\begin{abstract}
ABSTRAK
Anak yang dirawat di rumah sakit dapat mengalami stres yang berlebihan, ditunjukkan dengan gejala; marah, berontak, memukul, menangis, menolak makan, dan lain-lain. Salah satu upaya mengatasinya dengan bermain. Tujuan penelitian ini adalah mengidentifikasi hubungan faktor-faktor yang mempengaruhi pelaksanaan konsep terapi bermain terhadap penerapannya di Ruang Anak RS Husada. Desain penelitian deskriptif analitik dengan pendekatan cross sectional dengan menggunakan total sampel sebanyak 30 perawat anak. Hasil penelitian didapatkan hubungan antara usia perawat ( $\mathrm{p}$ value $0,002)$, pendidikan ( $\mathrm{p}$ value: 0,002$)$ pelatihan ( $\mathrm{p}$ value: 0,005$)$, pengalaman kerja ( $\mathrm{p}$ value: $0,002)$, pengetahuan ( $\mathrm{p}$ value: 0,005 ), fasilitas bermain ( $\mathrm{p}$ value: 0,008 ), dan kebijakan RS (p value: 0,007) terhadap penerapan konsep terapi bermain di ruang anak Rumah Sakit Husada. Diharapkan penelitian ini menjadi dasar penetapan terapi bermain sebagai salah satu program yang wajib dilaksanakan dalam memberikan asuhan keperawatan anak.
\end{abstract}

Kata kunci : Terapi bermain, hospitalisasi, anak

\begin{abstract}
Hospitalized children have a tendency to experience extreme stress by showing several symptoms, such as: anger, ructions, smack, crying, avoids eating, and many more. The most appropriate attempt of stress is by playing. The research aims to identify the factors related which influence the performance of playing as therapy according to the implementation in children's room at RS Husada. The methodology research is using analysis descriptive that approached by cross-sectional based on 30 pediatric nurses as total sample of research. The results of this research showed that there's the relation between nurse's age ( $p$ value: 0,002), education ( $p$ value: 0,002), training ( $p$ value:0,005), work experience ( $p$ value: 0,002), knowledge ( $p$ value: 0,005), playground facility ( $p$ value: 0,008) and hospital's policy ( $p$ value: 0,007) toward the implementation of playing as therapy in children's room at RS Husada. It is highly recommended for this research to be developed as foundation of playing therapy being one of compulsory implemented programs in giving nurture hospitality towards the children.
\end{abstract}

Keyword : playing therapy, hospitalized, pediatric 


\section{Pendahuluan}

Anak sangat rentan terhadap penyakit, oleh karena itu sebagai orang tua perlu memperhatikan kesehatan dan nutrisinya. Pada saat anak mengalami sakit dan tidak dapat diatasi dirumah dengan berobat jalan maka harus dirawat di rumah sakit. Tujuannya untuk menyembuhkan atau memperbaiki status kesehatan baik fisik maupun mental. Akan tetapi masuk rumah sakit membuat anak takut dan stress.

Masuk rumah sakit merupakan peristiwa yang dapat menimbulkan pengalaman traumatic khususnya pada anak-anak. Anak akan mengalami ketakutan dan ketegangan yang disebut stress hospitalisasi. Stres ini akan menimbulkan berbagai aksi seperti menolak makan, menangis, teriak, memukul, menyepak, tidak kooperatif atau menolak tindakan asuhan yang diberikan (Nursalam, 2005). Salah satu upaya untuk meminimalkan stres hospitalisasi dengan kegiatan bermain. Dalam kondisi sakit atau anak sedang dirawat di rumah sakit, aktivitas bermain tetap perlu dilaksanakan, namun harus disesuaikan dengan kondisi.

Hospitalisasi adalah suatu keadaan krisis pada anak saat dirawat di rumah sakit dimana anak harus beradaptasi dengan lingkungan rumah sakit (Wong, 2008). Sering kali hospitalisasi dipersepsikan oleh anak sebagai hukuman, karena masih banyak orang tua yang mengatakan “jika tidak mau makan nanti dibawa ke RS biar disuntik". Hal ini mengakibatkan perasaan takut pada anak untuk ke RS apalagi dirawat. Stress hospitalisasi pada anak menimbulkan reaksi agresif, marah, berontak, tidak mau bekerjasama dengan perawat (Supartini, 2004).

Beberapa faktor yang dapat menimbulkan stress hospitalisasi menurut (Utami, 2014) adalah; faktor lingkungan rumah sakit, perpisahan dengan orang yang terdekat/yang berarti, kurangnya informasi yang didapat anak dan orang tua, kehilangan kebebasan dan kemandirian, pengalaman yang berkaitan dengan pelayanan kesehatan, dan factor perilaku atau interaksi dengan petugas rumah 
sakit. Dampak yang umum terjadi akibat hospitalisasi adalah cemas, takut, sedih, dan tegang (Supartini, 2004).

Upaya untuk meminimalkan stress hospitalisai dapat dilakukan dengan mencegah atau mengurangi dampak perpisahan, mencegah perasaan kehilangan kontrol diri dan mengurangi atau meminimalkan rasa takut terhadap perlukaan tubuh. Salah satu upaya mencegah perasaan kehilangan kontrol diri dengan melibatkan orang tua dalam membuat jadwal kegiatan anak, latihan, bermain dan aktivitas lain dalam memberikan asuhan keperawatan. Supartini (2004) mengatakan bahwa anak membutuhkan orang tua selama proses hospitalisasi. Sedangkan menurut Elfira (2011) Keberadaan orang tua sangat penting untuk mendampingi anak selama menjalani perawatan di rumah sakit karena perpisahan dengan orang tua dapat memicu terjadinya kecemasan.

Upaya meminimalkan kecemasan, rasa takut terhadap perlukaan tubuh, dan meningkatkan kooperatif anak dapat dilakukan dengan terapi bermain. Terapi bermain berfungsi sebagai distraksi seperti bercerita, mengambar, menonton video kaset. Bercerita yang berkaitan dengan tindakan atau prosedur yang akan dilakukan akan memberikan gambaran pada anak apa yang harus dilakukan saat dilakukan prosedur. Diharapkan dengan memberikan gambaran telebih dahulu pada anak akan meningkatkan kooperatif saat dilakukan prosedur. Penelitian yang dilakukan Fricilia, dkk (2014) tentang pengaruh terapi bermain mewarnai gambar terhadap tingkat kecemasan pada anak usia prasekolah terjadi penurunan tingkat kecemasan dengan nilai rata-rata 5.26. Sedangkan penelitian Handayani dan Puspitasari di RS Panti Rapih menunjukkan ada pengaruh terapi bermain terhadap tingkat kooperatif anak usia $3-5$ tahun di Ruang Anak.

Terapi bermain merupakan salah satu intervensi keperawatan yang dapat mengurangi tingkat kecemasan dan meningkatkan tingkat kooperatif tindakan keperawatan pada anak yang dirawat di Rumah Sakit 
(Wong, 2004). Penelitian Mashudi S dan Moh. Zainal (2009) di RS Sampang yang berjudul Aplikasi Terapi Bermain Terhadap Respon Penerimaan Tindakan Invasif Pada Anak Prasekolah menyatakan respon penerimaan tindakan invasive pada anak prasekolah yang diberikan terapi bermain mengalami perubahan sikap menerima dengan baik dibandingkan dengan yang tidak diberikan terapi bermain.

Merujuk kepada konsep keperawatan anak mengenai terapi bermain atau kegiatan bermain pada setiap intervensi keperawatan anak, berikut merupakan contoh rujukan yaitu RS Ibu dan Anak Evasari Jakarta, ruang perawatan didisain sedemikian rupa dan diusahakan untuk dapat memenuhi kebutuhan anak selama dalam perawatan di rumah sakit. Ruangan tersebut diharapkan dapat mengurangi ketertinggalan anak dari kegiatan mereka sehari-hari, mengurangi kejenuhan dan menambah semangat untuk cepat pulih kembali. Ruang perawatan semacam ini, dapat menjadi inspirasi bagi rumah sakit lain untuk menjadikan ruang perawatan anak, menyenangkan dan memberi kesempatan pada anak untuk tidak tertinggal dari kemajuan karena sedang berada dalam perawatan. Ruangan IGD dindingnya berwarna pink sangat friendly (menyenangkan) anak-anak sehingga tak ada kesan spooky (menyeramkan) bagi anakanak.

Rumah Sakit Husada merupakan rumah sakit tipe B yang dilengkapi dengan pelayanan sub spesialis, salah satunya adalah pelayanan kesehatan anak. Pelayanan dilakukan di ruang rawat jalan dan rawat inap. Ruang rawat inap anak terletak di lantai tiga gedung Pratama yang terdiri dari Putra I, Putra III, Perina dan NICU-PICU. Putra I merawat pasien kelas I dan VIP terdiri dari 21 tempat tidur, sedangkan Putra III merawat pasien kelas dua dan tiga, berjumlah 26 tempat tidur. Masingmasing ruangan dilengkapi satu ruangan tindakan. Selain itu di ruang perawatan anak juga sudah dilengkapi satu ruang bermain dan sarana permainan sederhana yang terletak di Ruang Putra III.

Kegiatan terapi bermain di Rumah 
Sakit Husada saat ini belum terjadwal dengan baik dan lebih sering dilakukan oleh Mahasiswa Keperawatan yang sedang praktek lapangan. Permainan yang dilakukan lebih bersifat individu ketika pasien akan dilakukan tindakan invasif atau tindakan keperawatan lainnya guna mengurangi kecemasan dan meningkatkan kooperatif.

Dari hasil wawancara penulis tanggal 29 Januari 2014 dengan orang tua pasien yang anaknya sudah dirawat lima hari, menyatakan belum pernah ada aktivitas bermain di ruang bermain. Sedangkan wawancara dengan salah satu perawat di putra III kegiatan terapi bermain belum terlaksana secara optimal dan belum terjadwal secara rutin. Berdasarkan uraian diatas penulis tertarik untuk melakuan penelitian dengan rumusan masalah hubungan faktor-faktor yang mempengaruhi penerapan konsep terapi bermain terhadap pelaksanaanya di Ruang Anak Rumah Sakit Husada.

\section{Metode}

Penelitian ini menggunakan desain penelitian deskriptif analitik dengan pendekatan cross sectional, yang bertujuan mengidentifikasi faktorfaktor yang mempengaruhi penerapan konsep terapi bermain di Ruang Perawatan Anak RS Husada Jakarta. Populasi pada penelitian ini adalah seluruh perawat pelaksana yang bertugas di ruang perawatan anak Rumah Sakit Husada yang berjumlah 30 orang. Tehnik penelitian ini menggunakan total sampling yaitu seluruh perawat pelaksana di ruang perawatan anak RS Husada yang berjumlah 30 orang. Sebelum dilakukan pengambilan sampel ditentukan terlebih dahulu kriteria inklusi maupun eksklusinya. Kriteria inklusi adalah perawat pelaksana yang bertugas di ruang perawatan anak, mempunyai pengalaman minimal satu tahun di ruang perawatan anak, dan bersedia menjadi responden dengan menandatangani informed consent. Sedangkan kriteria eksklusi adalah perawat kepala ruangan, perawat yang sedang cuti dan sakit, dan perawat yang melakukan penelitian. Penelitian dilaksanakan di ruang perawatan anak RS Husada Jakarta. Penelitian dilaksanakan 
mulai dari uji kuisioner sampai pengumpulan data dari November 2014. Penelitia ini menggunakan kuesioner yang telah dilakukan uji validitas dan reliabilitas. Pernyataan valid akan digunakan dalam penelitian dengan jumlah 30 pernyataan. $(<\mathrm{r}$ table $=0,60)$.

\section{Hasil}

Hasil analisis univariat didapatkan

Tabel 1

Distribusi frekuensi responden di RS

Husada, November $2014(\mathrm{n}=30)$

\begin{tabular}{|c|c|c|c|}
\hline Variabel & Kategori & $\begin{array}{l}\text { Frekue } \\
\text { nsi }\end{array}$ & $\begin{array}{l}\text { Persentas } \\
\mathrm{e}(\%)\end{array}$ \\
\hline \multirow[t]{4}{*}{ Usia } & $20-27$ tahun & 13 & 43,3 \\
\hline & $28-35$ tahun & 4 & 13,3 \\
\hline & $36-45$ tahun & 8 & 26,7 \\
\hline & $46-55$ tahun & 5 & 16,7 \\
\hline \multirow{2}{*}{$\begin{array}{l}\text { Tingkat } \\
\text { Pendidikan }\end{array}$} & Rendah & 3 & 10 \\
\hline & Tinggi & 27 & 90 \\
\hline \multirow[t]{2}{*}{ Pelatihan } & Tinggi & 26 & 86,7 \\
\hline & Rendah & 4 & 13,3 \\
\hline \multirow[t]{3}{*}{ Masa kerja } & $<5$ tahun & 8 & 26,7 \\
\hline & $5-10$ tahun & 8 & 26,7 \\
\hline & $>10$ tahun & 14 & 46,6 \\
\hline \multirow{4}{*}{$\begin{array}{l}\text { Tingkat } \\
\text { pengetahuan }\end{array}$} & Baik & 17 & 56,7 \\
\hline & Cukup & 13 & 43,3 \\
\hline & Kurang & 0 & 0 \\
\hline & Tidak baik & 0 & 0 \\
\hline \multirow[t]{4}{*}{ Fasilitas } & Lengkap & 9 & 30 \\
\hline & Cukup lengkap & 9 & 30 \\
\hline & Kurang lengkap & 7 & 23,3 \\
\hline & Tidak lengkap & 5 & 16,6 \\
\hline \multirow[t]{2}{*}{ Kebijakan RS } & Lengkap & 21 & 70 \\
\hline & Tidak lengkap & 9 & 30 \\
\hline \multirow{4}{*}{$\begin{array}{l}\text { Tingkat } \\
\text { pengetahuan }\end{array}$} & Selalu & 14 & 44,6 \\
\hline & Sering & 6 & 20 \\
\hline & Kadang-kadang & 5 & 16,7 \\
\hline & Tidak pernah & 5 & 16,7 \\
\hline
\end{tabular}

Perawat di Ruang Anak Rumah

Sakit Husada terbanyak berada pada rentang usia 20-27 tahun sebanyak 13 orang (43.3\%), disusul rentang usia 36-45 tahun sejumlah 8 orang
(26.7\%), rentang usia 46-55 tahun sejumlah 5 orang (16.7\%), dan 4 orang $(13.3 \%)$ berusia antara $28-35$ tahun. Dengan demikian perawat pelaksana di ruang anak RS Husada paling banyak berusia 27- 45 tahun atau berada pada kategori dewasa muda.

Tabel 2

Analisis hubungan variable independen terhadap Penerapan Konsep Terapi Bermain di RS Husada, November $2014(n=30)$

\begin{tabular}{lll}
\hline \multicolumn{1}{c}{ Variabel } & $\begin{array}{c}\text { OR } \\
(95 \% \mathrm{CI})\end{array}$ & P value \\
\hline Usia & 0,362 & 0.002 \\
\hline Pendidikan & 0,245 & 0,002 \\
\hline Pelatihan & 0,121 & 0.005 \\
\hline Pengalaman kerja & 0,431 & 0.002 \\
\hline $\begin{array}{l}\text { Tingkat } \\
\text { pengetahuan }\end{array}$ & 0,857 & 0,005 \\
\hline Fasilitas bermain & 0,625 & 0.008 \\
\hline Kebijakan RS & 0,236 & 0.007 \\
\hline
\end{tabular}

Dilihat dari hubungan antara usia perawat dengan penerapan konsep terapi bermain memiliki nilai 0,002 $<$ nilai alpha yang artinya ada hubungan antara usia dengan penerapan konsep terapi bermain di ruang anak RS Husada. Hubungan antara tingkat pendidikan terhadap penerapan konsep terapi bermain memiliki nilai $0,002<$ nilai alpha yang artinya ada hubungan tingkat pengetahuan terhadap penerapan terapi bermain di ruang anak $\mathrm{RS}$ 
Husada. Hubungan antara pelatihan terhadap penerapan konsep terapi bermain memiliki nilai $0,005<$ nilai alpha yang artinya ada hubungan antara faktor pengetahuan perawat terhadap penerapan konsep terapi bermain di Ruang Anak RS Husada. Hubungan antara pengalaman kerja perawat terhadap penerapan konsep terapi bermain memiliki nilai 0,002 $<$ nilai alpha yang artinya ada hubungan antara faktor pengetahuan perawat terhadap penerapan konsep terapi bermain di Ruang Anak RS Husada. hubungan antara tingkat pengetahuan terhadap penerapan konsep terapi bermain memiliki nilai $0,005<$ nilai alpha, artinya ada hubungan antara tingkat pengetahuan trerhadap penerapan konsep terapi bermain di Ruang Anak RS Husada. Hubungan antara fasilitas terhadap penerapan konsep terapi bermain memiliki nilai 0,008 $<$ nilai alpha yang artinya ada hubungan antara tingkat pengetahuan terhadap penerapan konsep terapi bermain di Ruang Anak RS Husada. hubungan antara kebijakan RS terhadap penerapan konsep terapi bermain memiliki nilai $0,007<$ nilai alpha yang artinya ada hubungan antara tingkat pengetahuan terhadap penerapan konsep terapi bermain di Ruang Anak RS Husada

\section{Pembahasan}

Peneliti berasumsi bahwa seseorang pada usia dewasa awal mempunyai keingintahuan yang besar, kreatif, selalu ingin mencoba sesuatu yang baru termasuk ilmu atau teori-teori yang diperolehnya dan diharapkan pada usia tersebut mempunyai semangat untuk selalu belajar dan mau menerapkan teori atau ilmu baru. Termasuk didalamnya pada penerapan konsep terapi bermain. Hal ini sesuai teori menurut Peaget dalam Anwar (2007), pada usia dewasa muda seseorang lebih fleksibel, terbuka, kreatif dan sangat adaptif. Pendapat lain usia dewasa awal merupakan masa menunjukkan kreativitas, minat dan kemampuan individual dalam mewujudkan keinginan-keinginan dan kegiatankegiatan yang memberikan kepuasan sebesar-besarnya (E.B. Hurlock.1980.hal,252).

Berbeda dengan penelitian yang 
dilakukan oleh Ika Agustina dkk, tahun 2012 memaparkan bahwa ratarata respondennya berumur 41-50 tahun dengan jumlah presentase sebanyak $40 \%$ atau dewasa tua dan minoritas responden berada pada rentang usia 51-60 tahun sebanyak 2\%. Hal ini sesuai dengan teori Notoatmojo (2007) bahwa bertambahnya umur seseorang dapat berpengaruh pada pertambahan pengetahuan yang diperolehnya. Akan tetapi pada umur-umur tertentu mengingat atau menjelang usia lanjut kemampuan penerimaan atau mengingat suatu pengetahuan akan berkurang.

Tingkat pendidikan perawat di ruang anak RS Husada mayoritas termasuk dalam kategori pendidikan tinggi yaitu sejumlah 27 orang (90\%) dan berpendidikan rendah sejumlah 3 orang (10\%). Hal ini sejalan dengan penelitian yang dilakukan oleh Ika A dkk (2012) yang memaparkan bahwa rata rata pendidikan perawat pada kategori tingi dengan presentase 80 $\%$.

Peneliti berasumsi dengan pendidikan tinggi, pengetahuan yang dimiliki juga tinggi dan akan mempengaruhi kinerja yang lebih baik. Demikian pula dengan mayoritas perawat di Ruang Anak RS Husada yang termasuk kategori tinggi akan selalu menerapkan konsep terapi bermain dalam melakukan asuhan keperawatan. Hal ini terbukti dengan hasil penelitian bahwa $100 \%$ perawat dengan pendidiksn tinggi selalu menerapkan konsep terapi bermain dalam memberikan asuhan keperawatan pada anak yang dirawat di Ruang Rawat anak RS Husada.

Sesuai dengan pendapat Notoadmodjo (2007), pendidikan merupakan salah satu faktor yang mempengaruhi persepsi seseorang untuk lebih mudah menerima ide-ide baru. Selain itu, secara umum seseorang dengan pendidikan tinggi akan mempunyai pengetahuan yang lebih luas dibandingkan dengan seseorang yang tingkat pendidikannya lebih rendah. Menurut Gilles (1996) bahwa perawat yang perpendidikan tinggi mempunyai kemampuan bekerja yang lebih tinggi. Namun demikian tidaklah mutlak bahwa tingkat pendidikan perawat yang tinggi menjamin perawat tersebut 
menerapkan konsep terapi bermain saat bertugas.

Distribusi perilaku perawat ditinjau dari tingkat pendidikan menunjukkan semakin tinggi tingkat pendidikan perawat, maka perilaku perawat juga semakin baik. Sesuai dengan penelitian Supratman (2009) menunjukkan bahwa perawat dengan tingkat pendidikan tinggi selain memiliki ketrampilan juga memiliki dasar pengetahuan yang lebih baik dibandingkan perawat dengan tingkat pendidikan dibawahnya, sehingga kinerjanya cenderung lebih baik

Perawat pelaksana di Ruang Anak RS Husada mayoritas telah mengikuti pelatihan konsep dasar anak dalam kategori tinggi sejumlah 26 orang $(86.7 \%)$ dan dalam kategori rendah sejumlah 4 orang (13.3\%). Perawat yang telah mengikuti pelatihan dengan kategori tinggi selalu menerapkan konsep terapi bermain ketika memberikan asuhan keperawatan. Pelatihan konsep dasar anak erat kaitannya dengan kinerja perawat di ruang anak, tetapi tidak mutlak yang pernah beberapa kali mengikuti pelatihan selalu melaksanakan konsep dasar perawatan anak tersebut. Hal ini sesuai dengan tujuan pelatihan, yaitu meningkatkan kemampuan karyawan untuk melakukan pekerjaannya dengan lebih baik, sedangkan pelatihan di bidang keperawatan merupakan salah satu kegiatan pengembangan staf yang bertujuan untuk meningkatkan mutu sumber daya manusia. Seorang perawat, baik itu perawat manajer ataupun perawat pelaksana tentunya harus berubah sesuai dengan dinamika waktu dan tuntutan pelayanan keperawatan yang semakin kompleks dimana kualitas pelayanan sangat di utamakan. Oleh karena itu secara rutin perlu adanya pelatihan dan pengembangan perawat agar kemampuan kognitif, afektif, dan psikomotor sesuai dengan kebutuhan di bidangnya masing-masing.

Perawat di ruang anak RS Husada mayoritas berpengalaman kerja $\geq 10$ tahun. Masa kerja $\geq 10$ tahun adalah masa yang cukup berpengalaman dan sudah dianggap senior. Hal tersebut terjadi karena semakin lama 
perawat bekerja maka semakin banyak kasus yang ditanganinya, sehingga semakin meningkat pengalamannya.

Menurut

Notoatmodjo (2007) bahwa pengalaman dapat diperoleh dari pengalaman sendiri atau orang lain. Pengalaman yang sudah diperoleh dapat memperluas pengetahuan seseorang. Semakin banyak pengalaman seseorang maka memiliki pengetahuan yang lebih baik dan akan melaksanakan tugasnya sesuai dengan konsep.

Sesuai pendapat Soekarno (1997) bahwa manfaat pengalaman kerja adalah untuk kepercayaan, kewibawaan, pelaksanaan pekerjaan, dan memperoleh penghasilan. Seseorang yang telah memiliki masa kerja lebih lama apabila dibandingkan dengan orang lain akan memberikan manfaat diantarnya pelaksanaan pekerjaan akan berjalan lancar karena orang tersebut telah memiliki sejumlah pengetahuan, keterampilan, dan sikap.

Pengalaman kerja erat hubungan dengan senioritas dan yunioritas.
Asumsi umum yang sering berlaku dan diyakini adalah pegawai yang cukup senior dipandang telah memiliki kinerja yang tinggi, sedangkan yang yunior masih perlu dikembangkan dan dibina lagi. Terbukti pada hasil penelitian perawat di Ruang Anak RS Husada dengan pengalaman kerja $\geq 10$ tahun, $78,6 \%$ selalu menerapkan konsep terapi bermain.

Pengetahuan perawat di ruang anak RS Husada sebagian besar baik 17 orang $(56.7 \%)$ dan cukup sejumlah 13 orang (43.3\%). Responden dengan pengetahuan baik sebagian besar $70.6 \%$ selalu menerapkan konsep terapi bermain. Hal ini menunjukan meskipun berpengetahuan baik, tidak semua menerapkan konsep terapi bermain. Peneliti berasumsi, hal ini mungkin disebabkan belum adanya standard prosedur operasional dan kewajiban untuk menerapkan konsep terapi bermain baik secara individu maupun kelompok.

Pengetahuan perawat tentang konsep terapi bermain adalah semua informasi yang diperoleh perawat 
mengenai terapi bermain pada anak. Meningkatnya pengetahuan dapat menimbulkan perubahan persepsi dan kebiasan seseorang karena pengalaman dan penelitian ternyata perilaku disadari oleh pengetahuan akan lebih bertahan lama daripada yang tidak disadari oleh pengetahuan (Notoatmodjo, 2003). Tinggi rendahnya tingkat pengetahuan seseorang dapat dipengaruhi oleh ketepatan informasi yang ia didapat. Dimana salah satu faktor yang mempengaruhi pengetahuan seseorang yaitu informasi (Notoadmojo, 2010).

Responden di Ruang Anak RS Husada berpendapat fasilitas bermain yang tersedia lengkap sebanyak 9 orang (30\%), cukup lengkap 9 orang (30\%), dan yang lainnya berpendapat kurang lengkap. Berdasarkan hasil kuisioner fasilitas tersebut seluruh responden $100 \%$ berpendapat di ruang perawatan anak sudah ada ruangan khusus tempat bermain, namun $86,7 \%$ berpendapat belum ada daftar buku mainan dan inventarisasi, serta $66.6 \%$ mengatakan mainan yang tersedia belum sesuai dengan semua usia tahap perkembangan anak.

Asumsi peneliti dengan tersedianya fasilitas yang lengkap seseorang akan lebih mudah menerapkan suatu konsep. Sesuai dengan hasil penelitian Nurlina (2013) Fasilitas kerja merupakan faktor yang sangat berperan dalam penerapan standar asuhan keperawatan. Hasil penelitiannya menunjukkan responden yang merasa fasilitas kerja di RS cukup baik akan menerapkan standar asuhan keperawatan dengan baik. Namun demikian perawat di Ruang Anak RS Husada walaupun berpendapat fasilitas belum lengkap, sebagian besar sudah menjalankan konsep terapi bermain dalam memberian asuhan keperawatan. Terbukti dari hasil pengamatan peneliti rata-rata responden menggunakan alat permainan pasien yang dibawa dari rumah.

Kebijakan rumah sakit adalah penetapan Direktur/Pimpinan RS pada tataran strategis atau bersifat garis besar yang mengikat. Kebijakan ditetapkan dengan peraturan atau keputusan pimpinan 
RS yang dituangkan dalam pasalpasal di dalam peraturan/keputusan tersebut, atau merupakan lampiran dari peraturan/keputusan. Hasil penelitian di ruang anak anak RS Husada menunjukkan bahwa mayoritas responden berpendapat kebijakan RS tentang penerapan konsep terapi bermain sudah lengkap sejumlah 21 orang $(70 \%)$ dan yang berpendapat tidak lengkap sejumlah 9 orang $(30 \%)$. Berdasarkan hasil kuisioner ketidaklengkapan tersebut antara lain; tidak ada standar prosedur operasional penerapan terapi bermain $97 \%$ dan $93.3 \%$ berpendapat tidak ada nilai tambah maupun reward dari pimpinan $\mathrm{RS}$. Kegiatan terapi bermain harus menjadi bagian integral dari pelayanan kesehatan anak di rumah sakit (Brennan, 1994 dalam Supartini, 2004). Demi terlaksananya kegiatan terapi bermain diperlukan kebijakan rumah sakit. Dalam menjalankan kebijakan tersebut perlu disusun pedoman/panduan suatu prosedur, sehingga ada kejelasan langkahlangkah dalam melaksanakan kebijakan tersebut. Hal ini didukung penelitian yang dilakukan Ika A, dkk
(2013) di RS Pringadi Medan bahwa prosedur tetap merupakan faktor yang mendukung terlaksananya program terapi bermain. Hasil penelitian di ruang anak Rumah Sakit Husada menunjukkan bahwa responden rata-rata yang selalu menerapkan konsep terapi bermain sebanyak 14 orang (46.6\%) dan masih ada sebagian kecil yang tidak pernah menerapkan konsep terapi bermain sebanyak lima responden (16.7\%). Observasi dilakukan secara individual ketika perawat akan melalukan prosedur keperawatan baik tindakan invasive maupun non invasive dengan tujuan meningkatan kooperatif antara perawat dan pasien. Selama peneliti melakukan observasi belum pernah menemukan penerapan terapi bermain yang bersifat kelompok maupun prosedur pengobatan. Penerapan konsep terapi bermain di rumah sakit dapat dilakukan secara individu maupun kelompok (Supartini, 2004).

Hasil analisa menunjukan bahwa pvalue 0,002 (< nilai alpha 0.05$)$ yang artinya ada hubungan antara usia dengan penerapan konsep terapi bermain di Ruang Anak Rumah 
Sakit Husada. Hal ini sejalan dengan penelitian yang dilakukan oleh Ika A, dkk (2012) di RS Pringadi Medan yang menunjukkan bahwa usia mempunyai pengaruh terhadap pelaksanaan terapi bermain. Pendapat Fikri (2009) pada penelitiannya menunjukkan umur merupakan salah satu faktor yang berhubungan dengan perilaku perawat. Hasil distribusi perilaku perawat ditinjau dari umur menunjukkan bahwa perawat dengan usia di atas 35 tahun memiliki perilaku lebih baik dibandingkan perawat yang berusia di bawah 35 tahun. Hal ini juga diperkuat oleh penelitian yang dilakukan I Gusti Nyoman, Listiyana dan Sri Rahayu dengan judul "Hubungan Penerapan Perawatan Atraumatik Dengan Tingkat Kooperatif Anak Usia 1 - 3 tahun Saat Dilakukan Injeksi Intavena Selama Hospitalisasi Di Bangsal Anggrek RSUD Panembahan Senopati Bantul" dimana karakteristik responden perawat sebagian besar masih berusia muda yaitu antara 25 tahun sampai 30 tahun. Pada penelitian ini, dalam melakukan tindakan perawat tidak lupa berkomunikasi dan mengajak anak bermain terlebih dahulu sebelum melakukan tindakan, serta membicarakan hal - hal positif yang dapat membantu proses kesembuhan anak. Dukungan lain adalah penelitian Sumaryoko (2008) dengan judul "Hubungan Tingkat Pendidikan Dengan Tingkat Pengetahuan Perawat Tentang Terapi Bermain Pada Anak di RS Sewilayah Boyolali” yang menunjukkan bahwa semakin tinggi tingkat pendidikan responden, maka akan semakin baik tingkat pengetahuannya tentang terapi bermain pada anak.

Hasil analisa menunjukan bahwa pvalue $0,002, \mathrm{p}$-value $<0,05$ artinya ada hubungan antara tingkat pendidikan terhadap konsep penerapan terapi bermain di ruang anak RS Husada. Sejalan dengan penelitian Martsella (2013) dengan hasil bahwa ada hubungan yang positif antara tingkat pengetahuan perawat dengan perilaku perawat dalam meminimalkan kecemasan akibat hospitalisasi pada anak prasekolah di RSUD Dr. Moewardi dengan $\mathrm{p}$ value 0,012. Dukungan lain, pendidikan dapat 
mempengaruhi pengetahuan karena pendidikan sebagai usaha untuk mengembangkan kepribadian dan kemampuan (Hardiwinoto, 2011).

Dukungan lain adalah penelitian Achmad F \& Winarsih (2008) Adanya hubungan tingkat pendidikan perawat terhadap kinerja perawat di Rumah Sakit Umum Pandan Arang Kabupaten Boyolali, ditunjukkan dengan nilai chi-square sebesar 17.47, dan taraf signifikan yang dihasilkan kurang dari 5\% yaitu $\mathrm{p}=0,002$. Dilihat dari hubungan antara pelatihan terhadap penerapan konsep terapi bermain memiliki nilai $0,005<$ nilai alpha (0.05) yang artinya ada hubungan tingkat pengetahuan terhadap penerapan konsep terapi bermain di ruang perawatan anak RS Husada. Sejalan dengan penelitian Estelle (2011) bahwa pelatihan menunjukkan pengaruh yang signifikan terhadap kinerja perawat pelaksana.

Sejalan dengan penelitian Estelle (2011) bahwa pelatihan menunjukkan pengaruh yang signifikan terhadap kinerja perawat pelaksana. Hal ini sesuai dengan tujuan pelatihan, yaitu meningkatkan kemampuan karyawan untuk melakukan pekerjaannya dengan lebih baik, sedangkan pelatihan di bidang keperawatan merupakan salah satu kegiatan pengembangan staf yang bertujuan untuk meningkatkan mutu sumber daya manusia. Berbeda dengan penelitian Guslinawati (2012) tentang FaktorFaktor Yang Berhubungan Dengan Penerapan Komunikasi Therapeutik Di RSJKO Soeprapto Bengkulu, bahwa tidak ada hubungan antara pelatihan komunikasi terapeutik dengan penerapan komunikasi terapeutik dengan nilai $p=0,091$.

Hasil analisa antara pengalaman kerja terhadap penerapan konsep terapi bermain memiliki nilai 0,002 $<$ nilai alpha (0.05) yang artinya ada pengaruh antara tingkat pengetahuan terhadap penerapan konsep terapi bermain di ruang perawatan anak RS Husada. Penelitian ini sesuai dengan penelitian Inayatullah (2014), pengalaman kerja berpengaruh terhadap pengetahuan dan pengalaman klinik seorang perawat. Hal ini terjadi karena semakin lama 
perawat bekerja, maka semakin banyak kasus yang ditanganinya sehingga semakin meningkat kemampuanya. Pendapat ini sejalan dengan pendapat Panjaitan (2002) ada hubungan yang bermakna antara masa kerja dengan kinerja perawat pelaksana. Mitcheal (1982) dan Graito (1988) dalam Manurung (2003) mengemukakkan bahwa pengalaman kerja turut menetukan bagaimana perawat menjalankan fungsinya sehari-hari, karena semakin lama perawat bekerja, maka ia semakin terampil dan berpengalaman menghadapi masalah dalam pekerjaannya. Sedangkan penelitian yang dilakukan Ika A, dkk Ruang Anak RS Pringadi Medan didapatkan $63.3 \%$ responden berpengalaman kerja antara 5-10 tahun dan mempunyai pengaruh terhadap pelaksanaan terapi bermain.

Penelitian Achmad Faizin dan Winarsih (2008) menunjukkan adanya hubungan antara lama kerja perawat terhadap kinerja perawat di Rumah Sakit Umum Pandan Arang Kabupaten Boyolali, ditunjukkan dengan nilai chi-square sebesar 19,99, dan taraf signifikan yang dihasilkan kurang dari 5\% yaitu $\mathrm{p}=$ 0,000. Demikian pula penelitian Tarigan (2011) tentang Pengaruh Tingkat Pendidikan, Motivasi, Usia Dan Pengalaman Kerja Terhadap Kinerja Perawat Pada RSU. Dr. Pirngadi Medan menunjukkan nilai signifikan sebesar 0,042 $<0,05$ maka hasil tersebut menunjukkan bahwa variabel pengalaman kerja memiliki pengaruh yang dominan terhadap kinerja perawat.

Hasil analisa dari hubungan antara pengetahuan terhadap penerapan konsep terapi bermain memiliki nilai $0,005<$ nilai alpha (0.05) yang artinya ada hubungan tingkat pengetahuan terhadap penerapan terapi bermain di ruang perawatan anak RS Husada. Penilaian ini sejalan dengan penelitian Siti Haryani (2011) dengan judul Faktorfaktor yang Mempengaruhi Kinerja Perawat dalam Pelaksanaan Terapi Bermain pada Anak Usia Prasekolah di Ruang Rawat Inap Anak RSUP Dr. Kariadi Semarang. Berdasarkan analisis bivariat terdapat hubungan dan berpengaruh antara pengetahuan terhadap kinerja perawat dengan $\mathrm{p}$ value : 0,024 
Hal ini sejalan dengan penelitian yang dilakukan Ika A, dkk (2012) dengan judul Faktor-faktor yang Mempengaruhi Pelaksanaan Terapi Bermain di RS Pringadi Medan bahwa pengetahuan cukup mempengaruhi berjalan atau tidaknya pelaksanaan terapi bermain di ruang anak. Pada penelitian ini didapatkan hasil bahwa, responden yang memiliki tingkat pengetahuan baik sebagian besar $70.6 \%$. menerapkan konsep terapi bermain. Hal ini mengindikasikan bahwa memang benar terdapat hubungan antara tingkat pengetahuan tentang konsep asuhan keperawatan anak dengan penerapan konsep terapi bermain. Dengan pengetahuan yang baik seseorang cenderung berperilaku baik dan bertanggung jawab dalam menjalankan tugas pekerjaannya. Hal ini didukung oleh teori Notoatmodjo Pengetahuan atau kognitif merupakan domain yang sangat berperan untuk terbentuknya suatu tindakan seseorang.

Selain itu didukung oleh penelitian Martsella Dwi Indah Puspita tahun 2013 dengan judul "Hubungan
Tingkat Pengetahuan Perawat Dengan Perilaku Perawat Dalam Meminimalkan Kecemasan Akibat Hospitalisasi Pada Anak Prasekolah di RSUD Dr. Moewardi” yang menunjukkan bahwa terdapat hubungan yang signifikan antara pengetahuan perawat dengan perilaku meminimalkan kecemasan akibat hospitalisasi pada anak pra sekolah di RSUD Dr. Moewardi Surakarta. Hal ini juga sejalan dengan penelitian yang dilakukan oleh Lidia, Amatus dan Abram tahun 2013 dengan judul "Hubungan Perilaku Caring Perawat Dengan Stres Hospitalisasi Pada Anak Usia Todler Di Irina E Blu RSUP Prof. Dr. R. D. Kandou Manado" yang menunjukkan hasil semakin baik perilaku caring perawat maka anak tidak mengalami stres hospitalisasi dengan menunjukkan nilai $\mathrm{p}=0,032$. Hasil analisa dari hubungan antara fasilitas bermain terhadap penerapan konsep terapi bermain memiliki nilai $0,008<$ nilai alpha (0.05) yang artinya ada hubungan antara fasilitas terhadap penerapan konsep terapi bermain. dengan demikian fasilitas mempunyai pengaruh terhadap konsep terapi bermain di ruang 
perawatan anak RS Husada. Penelitian ini sesuai dengan Siti Haryani (2011) dengan judul Faktorfaktor yang Mempengaruhi Kinerja Perawat dalam Pelaksanaan Terapi Bermain pada Anak Usia Prasekolah di Ruang Rawat Inap Anak RSUP Dr. Kariadi Semarang bahwa fasilitas berhubungan dan berpengaruh terhadap kinerja perawat dalam pelaksanaan terapi bermain pada anak usia sekolah dengan nilai $\mathrm{p}$ value 0.001 . Selain itu didukung pula oleh penelitian Ika A, dkk (2012) bahwa fasilitas bermain cukup mempengaruhi berjalan atau tidaknya pelaksanaan terapi bermain di ruang anak.

Hasil analisa dari hubungan kebijakan terhadap penerapan konsep terapi bermain memiliki nilai $0,007<$ nilai alpha (0.05) yang artinya ada hubungan antara kebijakan RS terhadap penerapan konsep terapi bermain. Dengan demikian kebijakan RS mempunyai pengaruh terhadap penerapan konsep terapi bermain di ruang perawatan anak RS Husada. Hal ini senada dengan penelitian Ika A, dkk (2012) bahwa kebijakan RS cukup mempengaruhi dalam berjalan atau tidaknya pelaksanaan terapi bermain di ruang anak.

Wong, et all (2008) mengatakan untuk melaksanakan kegiatan terapi bermain diperlukan kebijakan yaitu ketentuan-ketentuan yang harus dilaksanakan dalam pelaksanaan aktifitas bermain dan protap yaitu prosedur kegiatan yang telah di tetapkan sebagai acuan perawat dalam melaksanakan kegiatan bermain.

\section{Kesimpulan}

Hasil penelitian menunjukkan fasilitas bermain mempunyai pengaruh terhadap penerapan konsep bermain pada anak. Mengingat ada beberapa fasilitas bermain di ruang anak yang belum lengkap, disarankan perawat ruang anak untuk merapikan mainan yang tersedia, membuat buku daftar mainan dan inventarisasi, melengkapi mainan sesuai usia anak, membuat jadwal terapi bermain kelompok, dan meningkatkan penerapan konsep terapi bermain lebih intensif. Disarankan manajemen rumah sakit, dapat 
menjadikan terapi bermain sebagai salah satu program yang wajib dilaksanakan dalam memberikan asuhan keperawatan anak. Selain itu mengingat belum adanya kebijakan dan standar operasional prosedur (SOP) tentang penerapan konsep terapi bermain, maka disarankan agar rumah sakit khususnya bidang keperawatan membuat standar operasional prosedur tentang penerapan konsep terapi bermain agar memudahkan perawat anak dalam melaksanakan program terapi bermain.

\section{Daftar Pustaka}

Agustina, I dan Nur, A S. (2013). Faktor-faktor yang Mempengaruhi Pelaksanaan Terapi Bermain. artikel. (ortalgaruda.org/download_ar ticle.php?...faktor\%20faktor\%20). diakses 30 Februari 2014.

Anggraeni \& Damajanti, K D. (2013). Efektivitas Penerapan Terapi Bermain Bola untuk Meningkatkan Kemampuan Motorik Kasar Pada Tunagrahita Ringan Kelas 1 SMPLB. Jurnal, Http://Ejournal.Unesa.Ac.Id diakses 21 Januari 2014

Astri D, (2013) Ruang bermain anak http://www.ideaonline.co.id/iD EA2013/Interior/RuangBermain-Anak diakses 21
Maret 2014

BSN. (2014). Produsen Wajib Menerapkan SNI Mainan Anak.

http://bsn.go.id/main/berita/ber ita_det/4961/Tahun-2014 diakses 21 Februari 2014.

Chusairi, dkk. (2013). Efektivitas Terapi Bermain Sosial Untuk Meningkatkan Kemampuan Dan Keterampilan Sosial Bagi Anak Dengan Gangguan Atism. Jurnal. http://www.ejurnal.com/2013/09/efektivitasterapi-bermain-sosialuntuk.html diakses 30 Mei 2014.

Dariyo, A. (2008). Psikologi Perkembangan Dewasa. Jakarta; Grasindo.

Dahlan, S. (2009). Langkah-langkah Membuat Proposal Penelitian Bidang Kedokteran dan Kesehatan. Jakarta: Agung Seto.

Depkes RI. (2009). Profil Kesehatan Indonesia. Jakarta: Depertemen Republik Indonesia http://ilmukesehatanmasyarakat.blogspot.com/2012 105/kategori-umur.html diakses 9 Jan 2014.

Elfira, E (2011) Pengaruh Terapi Bermain Dengan tehnik Bercerita Terhadap Kecemasan Akibat Hospitalisasi Pada Anak Usia Prasekolah Di Ruang Perawatan RSUP $\mathrm{H}$. Adam Malik Medan. http://repository.usu.ac.id/hand le/123456789/24484 diakses 10 Juni 2014. 
Estelle. (2011). Pengaruh Pelatihan Supervisi Klinik Kepala Ruangan Terhadap Kepuasan Kerja Dan Kinerja Perawat Pelaksana Di Ruang Rawat Inap Rumah Sakit Woodward Palu. Tesis. lontar.ui.ac.id/file?file $=$ digital/ 20280828...pdf diakses 21 Desember 2014.

Fricilia, E W, dkk. (2014). Pengaruh Terapi Bermain Mewarnai Gambar terhadap tingkat kecemasan pada anak usia pra sekolah Akibat hospitalisasi di ruang irina $\mathrm{E}$

Haryani, S. (2014) hubungan antara pengetahuan perawat dan motivasi dengan kinerja perawat dalam pelaksanaan terapi bermain pada anak usia prasekolah di ruang inap anak RSUP Dr. Karyadi Semarang. Jurnal.

http://jurnal.unimus.ac.id/index .php/psn12012010/article/view 11150. diakses 21 Desember 2014

Hidayat, A A. (2011). Metode Penelitian Keperawatan dan Tehnik Analisa Data. Jakarta: Salemba Medika.

Mashudi, S dan Moh, Z. (2009) Aplikasi Terapi Bermain Terhadap respons Penerimaan Tindakan Invasif Pada Anak Prasekolah.

http://lib.umpo.ac.id/gdl/down load.php?id=661. diakses 27 Mei 2014.

Notoatmodjo. (2005). Pendidikan dan Perilaku Kesehatan.
Jakarta : Rineka Cipta.

Rahmawati, H D dan Ni Putu D P. (2008). Pengaruh Terapi Bermain Terhadap Tingkat kooperatif Selama Menjalani Perwatan Pada Anak Usia Pra Sekolah (3-5tahun) Di Rumah sakit Panti Rapih Yogyakarta. Jurnal Kesehatan Surya Medika

Ridha, N. (2014). Buku Ajar Keperawatan Anak. Yogyakarta: Pustaka Pelajar.

Sudjiono, Y N. (2013). Konsep Dasar Pendidikan Usia Dini. Jakarta: Indeks.

Sugiyono. (2010). Metode

Penelitian Kuantitatif Kualitatif dan $R \& D$.

Bandung: Alfabeta.

Suci S dan Kili A. (2011). Aktivitas Bermain Mewarnai Dapat Meningkatkan Mekanisme Koping Adaptif Saat menghadapi Stres Hospitalisasi Pada Anak. Jurnal STIKES. Vol 5 No 2 Desember 2012 (puslit2.petra.ac.id/ejournal /index.

php/stikes/article/download). diakses 30 Mei 2014.

Supartini, Y. (2004). Konsep Dasar Keperawatan Anak. Jakarta: EGC.

Utami, Y. (2014). Dampak Hospitalisasi Terhadap Perkembangan Anak. Jurnal Ilmia

Wijayaningsih, K S. (2014). 
Psikologi Keperawatan. Jakarta: Trans Info Media.

Wong DL, (2004). Buku Ajar Keperawatan Pediatric.

Vol.1. Jakarta: EGC
Wong, ett all. (2008). Buku Ajar Keperawatan Pediatrik. vol.4. Jakarta: EGC. 